\author{
Трофрімов Антон \\ доктор мистецтва, \\ фаготовий музичний виконавець, \\ Ізмір, Турція \\ ORCID 0000-0003-4545-2388 \\ antonartist@hotmail.com
}

\title{
СТИЛЬОВІ ОСОБЛИВОСТІ РАННІХ СИМФОНІЙ Й. ГАЙДНА
}

Мета роботи - проаналізувати і окреслити значення ранніх партитур Й. Гайдна як важливої складової всієї його творчості в загальному соціокультурному контексті періоду ранньокласичного оркестру. Методологія дослідження визначається самим характером досліджуваної проблеми. У роботі застосовуються історико-стильовий і функціональний методи, що продовжує традицію вітчизняної музично-теоретичної школи і методологію дослідження оркестрових явищ, що склалася в системі вищої академічної музичної освіти України, яка поєднує теоретичний і історичний підходи до вивчення предмета. Специфіка теми дослідження зажадала виходу за межі мистецтвознавства до області міждисциплінарних знань (філософії та культурології). Наукова новизна даного дослідження визначається його матеріалом і ракурсом розгляду проблеми. Наукова праця присвячена дослідженню оркестрового стилю раннього Й. Гайдна. В роботі проаналізована проблематика ранньокласичного оркестру, а ранньокласичний оркестр видатного композитора розглядається як приватний прояв загального феномену, зіставляються оркестрові прийоми раннього Й. Гайдна з бароковою і зрілою класичної оркестровкою, де саме явище ранньокласичного оркестру виявляється представленим у контексті еволюції оркестрового мистецтва. Висновки. Оркестрове письмо раннього Й. Гайдна, що пов'язане з бароковим, в той же час виявляє в собі нові риси - відмова від continuo в симфоніях, зростання ролі духових, винахідливість у створенні оркестрової фактури, її індивідуалізація - що однозначно характеризує стилістику композитора як явище нової епохи - епохи класичного стилю. Безумовно, оркестровка раннього Й. Гайдна нерозривно пов'язана 3 ідіомами галантного ранньокласичного стилю, їй властива наявність «загальних місць», тембро-фактурних «топосів» свого часу. Але не можна не відзначити, що при досить скромному складі доступного на той час до його розпорядження оркестру, Й. Гайдн максимально використовував наявну темброву палітру для підкреслення деталей композиції в області її фактури, гармонії та форми. Звернення до давно засвоєних прийомів, поряд зі свободою підходу до створення кожної нової партитури - в цьому й полягає особливість оркестрового стилю раннього Й. Гайдна, що надає його музиці індивідуальне звучання, яке відоме всьому людство.

Ключові слова: Й. Гайдн, симфонія, симфонічний оркестр, оркестровий стиль, оркестрове письмо, ранньокласичний оркестр, класичний оркестр.

Трофимов Антон, доктор искусства, фаготовый музыкальный исполнитель, Измир, Турция

Стилевые особенности ранних симфоний Й. Гайдна

Цель работы - проанализировать и определить значение ранних партитур Й. Гайдна как важной составляющей всего его творчества в общем социокультурном контексте периода раннеклассического оркестра. Методология исследования определяется самим характером исследуемой проблемы. В работе применяются историко-стилевой и функциональный методы, что продолжает традицию отечественной музыкально-теоретической школы и методологию исследования оркестровых явлений, сложившуюся в системе высшего академического музыкального образования Украины, которая сочетает теоретический и исторический подходы к изучению предмета. Специфика темы исследования потребовала выхода за пределы искусствоведения в область междисциплинарных знаний (философии и культурологии). Научная новизна данного исследования определяется его материалом и ракурсом рассмотрения проблемы. Научная работа посвящена исследованию оркестрового стиля раннего Й. Гайдна. В работе проанализирована проблематика раннеклассического оркестра, а раннеклассического оркестр выдающегося композитора рассматривается как частное проявление феномена, сопоставляются оркестровые приемы раннего Й. Гайдна с барочной и зрелой классической оркестровкой, где само явление раннеклассического оркестра оказывается представленным в контексте эволюции оркестрового искусства. Выводы. Оркестровое письмо раннего Й. Гайдна, тесно связаное с барочным искусством, в то же время обнаруживает в себе новые черты - отказ от continuo в симфониях, возрастание роли духовых, изобретательность в создании оркестровой фрактуры, ее индивидуализация, что однозначно характеризует стилистику композитора как проявление новой эпохи - эпохи классического стиля. Безусловно, оркестровка раннего Й. Гайдна неразрывно связана с идиомами галантного раннеклассического стиля, ей присуще наличие «общих мест», тембро-фрактурных «топосов» своего времени. Нельзя не отметить, что при достаточно скромном составе доступного в то время в его распоряжение оркестра, И. Гайдн максимально использовал имеющуюся в наличии тембровую палитру для подчеркивания деталей композиции в области ее фактуры, гармонии и фрормы. Обращение к давно усвоенным приемам одновременно со свободой подхода к созданию каждой новой партитуры - в этом и заключается особенность оркестрового стиля раннего Й. Гайдна, что придает его музыке индивидуальное звучание, которое знакомо всему человечеству.

Ключевые слова: Й. Гайдн, симфония, симфонический оркестр, оркестровый стиль, оркестровое письмо, раннеклассический оркестр, классический оркестр.

Trofimov Anton, Doctor of Arts, bassoon musical performer, Izmir, Turkey

Style Features of the Early Symphonies by J. Haydn

The purpose of the article is to analyze and to define the role of the early Haydn's sheet music as an essential component of his whole artwork in the social-cultural context during the period of the early-classical orchestra. The

(C) Трофрімов А., 2019 
methodology of the research is defined by the very own nature of the researched problem. The historical-stylistic and functional methods are applied in this research, which keeps the tradition of the domestic musical theoretical school and the methodology of the research on the orchestra phenomenons going. Such an approach has emerged in the Ukrainian higher music education system, which combines both theoretical and historical approaches to the study of the subject. The specific nature of the topic demands to go beyond Art History to the field of interdisciplinary studies - Philosophy and Cultural Studies. The scientific novelty of the research is defined by its material and the perspective of looking at this issue. This scientific work focuses on the exploration of the Haydn's early orchestra style. The early orchestra's problematic has been analyzed in this research, and the early orchestra of this outstanding composer is considered as the particular case of the general phenomenon. There is also a comparison of early Haydn's orchestral techniques with baroque and mature orchestration in which the phenomenon of the early classical orchestra is presented in the context of the orchestra art's evolution. Conclusions. The early orchestra sheet music of Haydn concerned to baroque at the same time also demonstrates the new features - abandonment of the continuo in symphonies, increasing role of woodwinds, ingenuity in the creation of orchestra facture and its individualization which characterizes the composer's stylistics as a manifestation of the new era of classical style. The orchestration of early Haydn's is concerned with idioms of gallant early classical style, and it's characterized by timber textured "toposes" of its time. Despite the fact that the orchestra at his disposal was pretty modest back in those times, Haydn made the most of the tone palette he had had then to enhance details of the composition in the field of its facture, harmony, and form. The peculiarity of Haydn's early orchestra style lies in the appeal to well-known tricks along with freedom in selecting approaches to create new sheet music, and this gives his music an individual sounding famous to all humanity.

Key words: J. Haydn, symphony, symphony orchestra, orchestra style, orchestration, early classical orchestra, classical orchestra.

Актуальність теми дослідження. Вивчення різних форм прояву художнього мислення залишається актуальним завданням мистецтвознавства, оскільки воно спрямоване в кінцевому рахунку на продуктивне осягнення природи творчості, незважаючи навіть на те, що розглядаються епохи та стилі, що знаходяться на значній історичної дистанції від сьогодення. Одним з таких проявів творчої діяльності $€$ сукупність прийомів композиторського володіння оркестром - оркестрове письмо. Рання симфонічна творчість Й. Гайдна - мистецька сфера, яка надзвичайно цікава щодо еволюції його власного композиторського стилю, жанру симфонії, історії оркестру, зрештою. Розгляд оркестрового письма раннього Й. Гайдна дає можливість побачити перехід від ранньокласичного до зрілого класичного оркестру в межах одного композиторського стилю. Звичайно, що цей перехід відбувався різноспрямовано і припускав співіснування та розвиток різних (старих і нових) принципів, використання яких складає особливі риси стилістики композитора.

Мета роботи - проаналізувати і окреслити значення ранніх партитур Й. Гайдна як важливої складової всієї його творчості в загальному соціокультурному контексті періоду ранньокласичного оркестру.

Методологія дослідження. У роботі застосовуються історико-стильовий і функціональний методи, що продовжує традицію вітчизняної музично-теоретичної школи і методологію дослідження оркестрових явищ, що склалася в системі вищої академічної музичної освіти України, яка поєднує теоретичний і історичний підходи до вивчення предмета.

Стан наукової розробки проблеми. Основні наукові роботи, що присвячені оркестровому стилю симфоній Й. Гайдна, належать закордонним дослідникам. В першу чергу слід назвати американського мистецтвознавця, автора п'ятитомної монографії та праці, присвяченого симфонічним творам Й. Гайдна - Р. Лендона [7]. Величезна дослідницька робота Р. Лендона отримала продовження в його наступній діяльності як редактора критичного видання всіх симфоній Й Гайдна [6] та як засновника гайднівського товариства.

Новий етап в дослідженні творчості Й. Гайдна насамперед пов'язаний з роботою Інституту Гайдна (Joseph Haydn-Institut) та видатних вчених, що входили до його складу (С. Герлах, Г. Федер, Дж. Вебстер), а також з появою нового академічного видання зібрання творів композитора [11]. Наступне покоління дослідників представлено в публікаціях, початок яким було покладено в 60-і роки XX ст., яке сорормувало оновлену текстологічну панораму і запропонувало своє трактування деяких принципових мистецтвознавчих питань, наприклад, пов'язаних з інструментарієм капели Й. Гайдна та наявністю «basso continuo» (генерал-басу) в його симфоніях. Представлена робота орієнтується саме на дане зібрання творів як на найбільш сучасне й авторитетне, яке максимально враховує всі джерела, що дійшли до нашого часу.

Накова новизна дослідження. Наукова праця присвячена дослідженню оркестрового стилю раннього Й. Гайдна. В роботі проаналізована проблематика ранньокласичного оркестру, а ранньокласичний оркестр видатного композитора розглядається як приватний прояв феномену, зіставляються оркестрові прийоми раннього Й. Гайдна з бароковою і зрілою класичної оркестровкою, де сам феномен ранньокласичного оркестру виявляється представленим у контексті еволюції оркестрового мистецтва.

Виклад основного матеріалу. Симфонії Й. Гайдна - найважливіше явище в історії оркестру XVIII століття. Їх дослідження важливо не тільки саме по собі, але й для розуміння музичнокультурного процесу даної епохи. Значення пізніх партитур (Паризьких, Лондонських симфоній) як високих класичних зразків жанру розкрито в великій кількості присвячених їм досліджень. Розгляд ранніх 
творів композитора, що хронологічно належать до ранньокласичесного періоду в історії музики, видається не менш важливим для мистецтвознавчої науки.

Взагалі, Й. Гайдном було створено 106 симфоній, з яких ранніми прийнято вважати твори (до цього періоду відносяться 64 партитури), що написані з 1757 року (поява першої симфонії) до 1774 року. Аргументом у виборі верхньої хронологічної межі для сучасних західних вчених (С. Герлах та інші) прислужила досить знаменна деталь - поява у партитурі самостійної нотної системи фагота. До 1774 року фагот разом із віолончеллю та контрабасом у партитурах гайдновских симфоній за інерцією трактувався як учасник групи генерал-баса та в партитурі окремо не виписувався. Після цієї дати ситуація змінюється докорінно, оскільки в кожній симфонії з'являється окрема партія одного або двох фаготів. Створені на близькій часовій дистанції від епохи бароко, ранні партитури органічно вбирають в себе деякі її стильові особливості, але в той же час демонструють й значний рух вперед. Іншими словами, ранні симфонії нібито відображають шлях переходу від оркестрового стилю однієї епохи до оркестровому стилю іншої, причому сама кількість партитур дозволяє більш пильно, нібито покадрово розглянути процес цього переходу, який в реальному житті відбувається майже невловимо.

Оркестр взагалі вельми багатолике явище, тому й поняття оркестру також має під собою різні смислові шари. Дослідниця музичного мистецтва Н. Ксенофонотова виділяє у цьому понятті соціокультурний, інструментальний і іманентно-композіційний аспекти [3, 4-5]. У першому випадку оркестр виступає, крім іншого, й як система професійних функцій його учасників, а у другому, оркестр розуміється як комплекс тембрів, пов'язаний з відібраним часом інструментарієм, кожна одиниця якого також має своє амплуа в загальній системі оркестрових засобів, що використані композитором.

У вітчизняному музикознавстві в періодизації оркестру прийнято виокремлювати епоху класицизму з характерними для неї принципами оркестровки, всередині якої розрізняють два типи оркестру: ранньокласичний (1740-80-ті роки) і класичний (з 1780-х до 1810-х років) [1]. Раньокласичний етап був підготовлений періодом пізнього бароко, від якого були успадковані змінність складу, камерне письмо, деякі принципи оркестровки (наприклад, гра інструментів «colla parte»). У раньоклассичний період інструментування поступово набуває нового статусу, з мобільного стаючи стабільним елементом композиції, важливою і незмінною складовою тексту музичного твору. Це знаходить відображення і в прагненні до все більш повної фріксації інструментування в партитурі, яка з часом стає загальноприйнятою.

Зміна статусу інструментування було пов'язано й з тенденцією до стабілізації оркестрового складу - з'явилася необхідність в певному універсальному інструменті для точного втілення композиторського задуму. Відповідним інструментом став в XIX столітті симфонічний оркестр. Проміжною ланкою між різноманітністю оркестрових колективів епохи бароко і сталим парним складом класицизму з'явився раньоклассичний оркестр, у якому ще немає рис повної сталості, але вже намічена певна тенденція до її появи.

Під впливом стабілізації складу, що сталася на етапі зрілого класичного оркестру, різноманітність, яка властива ранньокласичному періоду, виявилася у певній мірі стертою і недооціненною. Деякі симфонії Й. Гайдна з «скороченим» складом (симфонії № 27 і № 37) довгий час були відомі як симфонії, що написані для традиційного ранньокласичного складу з гобоями та валторнами. Тільки завдяки музикознавчим дослідженням останнього десятиліття минулого століття стало відомо, що партії другої пари духових були приписані пізніше, щоб, ймовірно, з метою продажу доповнити склад симфоній до найбільш поширеного, який, до кінця відповідного століття став вважатися стандартним обов'язковим мінімумом [5].

У той же час інструментування в ранньокласичну епоху, знаходячи статус стабільного елемента композиції, все ще було тісно пов'язано із зовнішніми обставинами - можливостями, що перебували в розпорядженні композитора. Тут маються на увазі самі оркестри, для яких писав композитор, їх інструментарій, кількість музикантів, тощо. Ця особливість ранньокласичного інструментування помітне й на прикладі ранньої оркестрової творчості Й. Гайдна.

Я зазначалося вище, інструментарій, його можливості - вельми важливий фактор, що впливає на манеру оркестрового письма. По-перше, мова йде про склад оркестру, з яким працював композитор. 3 ним, наприклад, пов'язана відсутність у ранніх партитурах Й. Гайдна кларнета, який тим часом вже активно входив до оркестрової практики. По-друге, на оркестрове письмо впливала й конструкція інструментів, яка в середині XVIII ст. значно відрізнялася від сучасної. Серед інструментів, до яких звертався Й. Гайдн, ця позиція головним чином відноситься до мідних духових інструментів (у першу чергу до валторни), а також до контрабасу. У ранніх симфоніях композитора зустрічаються найрізноманітніші лади натуральних валторн, причому не тільки найбільш поширені в епоху раннього класицизму - B-basso, C-basso, D, Es, E, F, G, A, B-alto, C-alto, але і рідко зустрічалися - Fis i H.

Деяку складність представляє питання, пов'язане з використанням контрабасу. У ранньокласичну епоху i, зокрема, у Й. Гайдна, його трактування в оркестрі демонструє рубіжний кордон між бароко, коли панувало ансамблеве письмо з вільним виділенням солістів із загального ансамблевого звучання, та зрілим класицизмом, де оркестрова тканина струнних мислилася як сукупність партій, що виконуються, як правило, групами музикантів. У ранніх партитурах Й. Гайдна контрабас постає в двох амплуа. Перше амплуа - контрабас акомпанує: інструмент як учасник групи контінуо грав по партії 
Basso разом з віолончеллю і фаготом, а друге амплуа - сольне. Таке несподіване для класичної епохи амплуа контрабаса-соліста в симфоніях № 6, 7, 8, 72, 31 говорить про релікт барочного концертного принципу, який зазнає певних жанрових меж.

Таким чином, у ранніх симфоніях Й. Гайдна була група басових інструментів, які виконували функцію «контінуо». У партитурі вона була представлена рядком з написом Basso або - значно рідше Basso continuo. До цієї групи інструментів оркестру належали віолончель, фрагот і контрабас. Клавішний інструмент, судячи по всьому, не входив до складу групи контінуо в симфоніях. Така точка зору підтверджується тим, що в автографах партитур і партій в симфоніях Й. Гайдна немає цифровок генерал-баса або вказівок на участь клавесина, тоді як у вокальних творах, супроводжуваних оркестром, вони зустрічаються постійно.

Своєрідність гайдновских партитур як ранньокласичних зразків, в яких органічно поєднується старі і нові принципи, знаходить вираз у такому явищі як прийом гри «colla parte», поширений в епоху бароко, але зникаючий у період класичного оркестра. У ранніх партитурах Й. Гайдна прийом «соlla parte» проявляється не тільки буквально - як письмова вказівка будь-якому інструменту грати по партії іншого, але й побічно - як прийом точної дубліровки навіть при відсутності відповідного позначення. В цьому відношенні особливу увагу звертає на себе трактування у творчості раннього Й. Гайдна партій фагота і альта, які при грі colla parte, як правило, не виписувалися в партитурі докладно.

Особливо показово зміна ставлення до трактування фагота за періоду часу з 1757 по 1774 роки, що розглядається у дослідженні. У цей період чітко помітна тенденція до відходу від принципу гри фагота col basso, його відокремлення від басової партії контінуо. Так барокові уявлення про фрагот як інструмент контінуо змінюються ставленням до нього як до інструменту з самостійною партією. Відокремлення фагота від басової партії стало кроком на шляху до формування оркестрової групи дерев'яних духових інструментів. Після цього пункту еволюції оркестра барокові риси проявляються в оркестровці все менше, а класичні - все більше.

Типологічно прикордонний статус ранньокласичного оркестру, охарактеризований досі через його зовнішні риси, виявляється в ранніх симфоніях Й. Гайдна й під час аналізу самого оркестрового письма. У творчості раннього Й. Гайдна ми пропонуємо виділяти особливий тип симфонії, для якого характерне включення соло інструментів протягом однієї або всіх її частин. До нього відносяться вісім симфоній, що написані в ранні естергазієвські роки (з 1761 по 1765): симфонії №№ 6, 7, 8, 72, 31, 36, 13, 24 (частково це зберігається ще в трьох - №№ 30, 41, 51). У всіх цих творах як мінімум повільна частина включає до себе сольну партію (партії), яка розрахована на всю частину. Симфонії з концертуючими інструментами включають безліч спільних рис з бароковим concerto grosso. Cеред них - можлива наявність декількох солістів, що звичайно для барочного концерту, принцип концертування, основоположний для оркестрової культури епохи бароко, використання звичайних для concerti grossi позначень. Частини, де безперервно виконує соло тільки один інструмент, схожі з частинами сольного барочного концерту.

У той же час у симфоніях Й. Гайдна з концертуючими інструментами є й відмінні від бароко нові риси. Так, вони написані у традиційній для ранньокласичного часу формі четирехчастного циклу 3 початковим алегро, повільною частиною, менуетом з тріо і швидким фіналом. Відрізняється й сам характер інструментування, який, незважаючи на слідування барочному принципу концертування - чергуванню soli i tutti, являє собою новий тип оркестровки з більш рухливим тембро-фрактурним ритмом. Однак жанр симфоній Й. Гайдна з концертуючими інструментами не слід ототожнювати з жанром концертної симфонії, який сформувався пізніше - в 1780-90-х роках.

Соло в ранніх симфоніях Й. Гайдна виявляє специфіку саме ранньокласичного оркестрового письма. Пізніше під принципом соло в оркестрі стала розумітися яскрава індивідуалізована партія, доручена одному інструменту, який виділений з оркестру. У ранньоклассическному оркестрі ситуація більш багатозначна. Для ранньокласичного оркестрового письма критерієм соло $є$ не сама по собі ступінь індивідуалізації матеріалу, яким воно представлено, скільки письмово встановлений у партитурі статус відособленості інструментальної партії, яка по-різному вписується до контексту оркестрової тканини.

Відомо, що інструментування класичної симфонії характеризується тісним взаємозв'язком між динамікою формоутворення та вибором конкретних оркестрових засобів. У XVIII ст. оформилися певні «закони» з вибудовування тембрового профрілю симфонії. Так у циклі були «регламентовані» зони яскравого, туттійного звучання і звучання більш прозорого, легкого. До перших у крупному плані ставилися початкове алегро, менует і фінал, до других - повільна, як звичайно, друга частина симфонії, де переважало звучання струнних та тріо менуету з характерними для нього соло. У ранніх симфоніях втілення тембрової архітектоніки циклу постає перед нами в найрізноманітніших варіантах - від найбільш простих (з мінімальною кількістю градацій щільності оркестрової тканини) до вельми складних (з використанням різних прийомів, наприклад, введення соло партій, що дозволяють досягти більшого числа можливих градацій оркестрового звучання).

Суттєвою дослідницькою проблемою, пов'язаною з меншим, ніж цикл, рівнем, є встановлення зв'язку тембро-фактурного ритму з формою кожної частини. У цілому в кожній з симфоній Й. Гайдна можна виділити однорідні тембро-фрактурні секції, які по своїй протяжності можуть бути самими різни- 
ми - від одного такту до цілої частини. Членування на секції не завжди буде збігатися з розподілом форми всередині частини і не завжди буде безпосередньо пов'язано з вирішенням проблеми безперервності або, навпаки, питання членування у розгортанні музичної тканини твору. Зв'язок із формою виявляється на рівні вибору характеру і частоти змін секцій в залежності від частини симфонії. Найбільші межі форми обов'язково маркуються зміною не тільки в оркестровому складі, а й характеру інструментування. В цілому можна зробити наступний висновок щодо характеру темпу темброфактурних змін у частинах циклу: найбільш статичною виявляється друга - повільна частина; найбільш динамічною і мінливою - перша та заключна частини циклу; менует і фінал, як правило, представляють собою компроміс.

Можна сказати, що питання темпу змін в оркестровій тканині симфоній показує якість нового етапу гайднівського письма в порівнянні з бароковим оркестром, якому, в цілому, була властива темброво-фрактурна статика. Вона могла проявлятися в повній відсутності тембрових змін (коли партія одного інструмента або ансамблю закріплюється за певним матеріалом або фактурною функцією в рамках цілої частини, чи будь-якого її розділу) або у відсутності переходів між змінами інструментальних складів. Таким постає й оркестр Й. Гайдна у II, III частинах циклу і в деяких фріналах ранніх симфоній. У I частині інструментування набагато більш жваво відгукується на формі. Тут втілюється інша - динамічна - концепція світосприйняття, зміни відбуваються зсередини безпосереднього перебігу самої музики, один тип письма на очах перетворюється в інший. Примітно, що в ранніх симфоніях Й. Гайдна старий статичний тип сусідить поруч з тим новим динамічним типом письма, що формуються.

Висновки. Оркестрове письмо раннього Й. Гайдна, котре пов'язане з бароковим, в той же час виявляє в собі нові риси - відмова від continuo в симфоніях, зростання ролі духових, винахідливість у створенні оркестрової фрактури, її індивідуалізація - що однозначно характеризує цей стиль як явище нової епохи - епохи класичного стилю. Безумовно, оркестровка раннього Й. Гайдна нерозривно пов'язана з ідіомами галантного ранньокласичного стилю, їй властива наявність «загальних місць», тембро-фрактурних «топосів» свого часу. Але не можна не відзначити, що при досить скромному складі доступного на той час до його розпорядження оркестру, Й. Гайдн максимально використовував наявну темброву палітру для підкреслення деталей композиції в області її фактури, гармонії та фрорми. Звернення до давно засвоєних прийомів поряд зі свободою підходу до створення кожної нової партитури в цьому й полягає особливість оркестрового стилю раннього Й. Гайдна, що надає його музиці індивідуальне звучання, яке знає все людство.

\section{תimepamypa}

89.

1. Барсова И. Оркестр // Музыкальная энциклопедия. Москва: Изд-во Сов. энциклопедия 1978. Т. 4. С.

2. Бородавкин С. А. Эволюция оперного оркестру в XVII-XVIII веках: от Я. Пери до В. А. Моцарта. Одесса : Печатный дом, Друк Південь, 2011. 540 с.

3. Ксенофонтова Н. Камерный оркестр в музыке первой половины XX века. Автореферат дисс. канд. искусствоведения. Москва, 1984. 24 с. С. 4-5.

4. Коробецька С. Ю. Оркестровий стиль: теорія, історія, сучасність : монографрія. Київ: Видавництво національного педагогічного університету ім. М. П. Драгоманова, 2011. 332 с.

5. Gerlach S., Scheideler U. Vorwort. Kritischer Bericht // Joseph Haydn Werke. Reihe 1. Bd. 1: Sinfonien um 1757-1760/61. Partitur. München: G. Henle Verlag, 1998. P. 245-297.

6. Joseph Haydn, Kritische Ausgabe sämtlicher Symphonien, hrsg. v. H. C. Robbins Landon. Wien: Universal Edition, 1963-1967.

7. Landon H.C.R. Haydn: Chronicle and Works. 5 vols. London: Thames and Hudson, 1976-1980. Vol. I: Haydn: the Early Years 1732-1765 (1980). 656 p.

8. Landon H.C.R. Haydn: Chronicle and Works. 5 vols. Vol. II: Haydn at Eszterháza 1766-1790 (1978). 800 p.

9. Landon H.C.R. The Symphonies of Joseph Haydn. London: Universal Edition \& Rockliff, 1955. 862 p.

10. Spitzer J., Zaslaw N. The birth of the orchestra. History of an institution, 1650-1815. Oxford - New York: Oxford University Press. 2004. 614 p.

11. Werke Joseph Haydn. München : G Henle, 2006, 279 p.

\section{References}

1. Barsova, Y. (1978). Orchestra. Musical Encyclopedia. Moscow: Publishing House Sov. Эntsyklopedyia. Vol. 4. [in Russian].

2. Borodavkyn, S. A. (2011). volution of the opera orchestra in the XVII-XVIII centuries: from Ja. Peri to V. A. Mozart. Odesa: Printing House, Druk Pivden [in Russian].

3. Ksenofontova, N. (1984). Chamber Orchestra in the music of the first half of the XX century. Extended abstract of candidate's thesis. Moscow, pp. 4-5 [in Russian].

4. Korobetska, S. Yu. (2011). Orchestral style: theory, history, present : monograph. Kyiv: Publishing House of the National Pedagogical University. M.P. Dragomanov [in Ukrainian].

5. Gerlach, S., \& Scheideler, U. (1998). Vorwort. Kritischer Bericht. Joseph Haydn Werke. Reihe 1. Bd. 1: Sinfonien um 1757-1760/61. Partitur. München: G. Henle Verlag, pp. 245-297. [in German].

6. Joseph Haydn, Kritische Ausgabe sämtlicher Symphonien, hrsg. v. H. C. Robbins Landon. Wien: Universal Edition, 1963-1967. [in German]. 